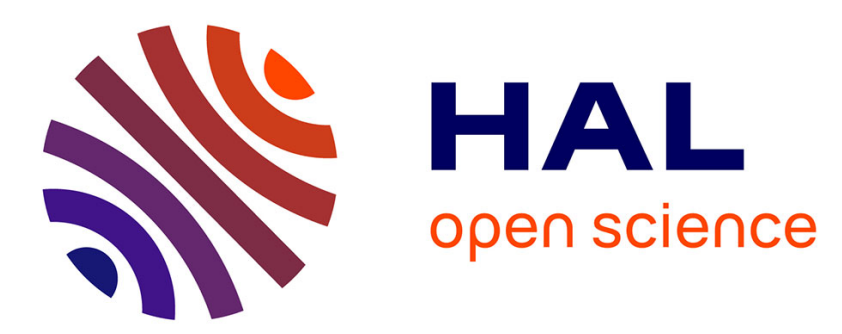

\title{
Modeling the control of the desorption rate of hydrogen released from the adsorption storage bed to supply a fuel cell.
}

\author{
Djamel Selloum, Sophie Tingry
}

\section{- To cite this version:}

Djamel Selloum, Sophie Tingry. Modeling the control of the desorption rate of hydrogen released from the adsorption storage bed to supply a fuel cell.. International Journal of Hydrogen Energy, 2020, 45, pp.17605-17612. 10.1016/j.ijhydene.2020.04.120 . hal-03009662

\section{HAL Id: hal-03009662 \\ https://hal.science/hal-03009662}

Submitted on 20 Nov 2020

HAL is a multi-disciplinary open access archive for the deposit and dissemination of scientific research documents, whether they are published or not. The documents may come from teaching and research institutions in France or abroad, or from public or private research centers.
L'archive ouverte pluridisciplinaire HAL, est destinée au dépôt et à la diffusion de documents scientifiques de niveau recherche, publiés ou non, émanant des établissements d'enseignement et de recherche français ou étrangers, des laboratoires publics ou privés. 


\title{
Modeling the control of the desorption rate of hydrogen released from the adsorption storage bed to supply a fuel cell
}

\author{
NoureddineCherrad ${ }^{a}$, DjamelSelloum $^{b}$, Sophie Tingryc \\ ${ }^{a}$ University Kasdi Merbah of Ouargla, Faculty of Applied Sciences, Department of Mechanical Engineering, Ouargla, \\ Algeria \\ ${ }^{b}$ Lab. Dynamic Interactions and Reactivity of Systems, Kasdi Merbah University, Ouargla 30000, Algeria \\ ${ }^{\mathrm{c}}$ Institut Européen des Membranes, UMR 5635ENSCM-UMII-CNRS,Montpellier, France.
}

\begin{abstract}
The storage of hydrogen by adsorbent materials has been addressed by several researchers. These materials can serve as a reservoir of hydrogen at a very lower temperature and the emptying operation for fuel cells is simply heating the adsorbent bed. However, in order to maximize the ability of the adsorbent materials to meet the instantaneous hydrogen demand, adequate knowledge of desorbed hydrogen flow rate (DHR) must be investigated. The objective of this study is to model the control of the DHR induced by heating. The results show that the excess of hydrogen stored in the adsorbent material can be completely released at room temperature and the DHR increases with temperature. A solution is proposed for stabilizing the DHR, which consists in controlling the fuel cell supply section and, consequently, the power to be produced.
\end{abstract}

\section{Keywords:}

Hydrogen; DHR modeling; Excess amount; Desorption; Fuel cell; Power Nomenclature

\begin{tabular}{|l|l|l|}
\hline Symbol & \multicolumn{1}{|c|}{ Description } & Unit \\
\hline $\mathrm{F}$ & Faraday's constant & $\mathrm{C} / \mathrm{mol}$ \\
\hline $\mathrm{m}_{\mathrm{d}}$ & Adsorbent material mass & $\mathrm{kg}$ \\
\hline $\mathrm{m}_{\mathrm{h}}$ & Excess amount of stored hydrogen & $\mathrm{kg} / \mathrm{kg}$ \\
\hline $\mathrm{M}_{\mathrm{h}}$ & Molar mass of hydrogen & $\mathrm{kg} / \mathrm{mol}$ \\
\hline $\mathrm{n}_{\max }$ & $\begin{array}{l}\text { Limitation of adsorption for maximum filling of the entire volume } \\
\text { of the adsorption space }\end{array}$ & $\mathrm{mol} / \mathrm{kg}$ \\
\hline
\end{tabular}




\begin{tabular}{|l|l|l|}
\hline $\mathrm{P}$ & Static pressure in the adsorbent bed & $\mathrm{Pa}$ \\
\hline $\mathrm{P}_{0}$ & Saturation pressure & $\mathrm{Pa}$ \\
\hline $\mathrm{P}_{\mathrm{atm}}$ & Atmospheric pressure & $\mathrm{Pa}$ \\
\hline $\mathrm{P}_{\mathrm{e}}$ & Power & $\mathrm{W}$ \\
\hline $\mathrm{P}_{\mathrm{i}}$ & Static pressure at the fuel cell inlet & $\mathrm{Pa}$ \\
\hline $\mathrm{q}_{\text {des }}$ & Mass flow of desorbed hydrogen & $\mathrm{kg} / \mathrm{s}$ \\
\hline $\mathrm{R}$ & Universal gas constant & $\mathrm{J} /(\mathrm{mol} . \mathrm{K})$ \\
\hline $\mathrm{S}$ & Flow section & $\mathrm{m} 2$ \\
\hline $\mathrm{t}$ & Time & $\mathrm{s}$ \\
\hline $\mathrm{T}$ & Temperature & $\mathrm{K}$ \\
\hline $\mathrm{V}_{\mathrm{a}}$ & Adsorption volume & $\mathrm{m} / \mathrm{kg}$ \\
\hline $\mathrm{V}_{\text {des }}$ & Desorption velocity & $\mathrm{m} / \mathrm{s}$ \\
\hline$\alpha$ & Free enthalpy characterizing adsorption & $\mathrm{J} / \mathrm{mol}$ \\
\hline$\beta$ & Entropy of free energy characterizing adsorption & $\mathrm{J} /(\mathrm{mol} . \mathrm{K})$ \\
\hline$\Delta \mathrm{t}$ & Step of time & $\mathrm{s} / \mathrm{m}^{3}$ \\
\hline$\rho_{\mathrm{g}}$ & Density of the bulk gas & \\
\hline
\end{tabular}

\section{Introduction}

Most of the energy used is produced from fossil fuels, which requires a lot of time to be renewable. Although these energies are less expensive, they must meet the challenge of replacing them with renewable and environmentally friendly energies [1]. Power to hydrogen is a promising solution for storing variable Renewable Energy (RE) to achieve a 100\% renewable and sustainable hydrogen economy [2]. For this reason, hydrogen appears as a potential alternative to fossil fuels and it became one of the most abundant elements on the planet [3]. In the ever growing demand of 
future energy resources, production reaction of this fuel has attracted much attention among the scientific community [4] and it can be obtained from many sources such as water, biomass, natural gas, ethanol, etc. [3].

Although hydrogen is considered to be one of the most promising green fuels, its efficient and safe storage and use still raise several technological challenges [5]. The reason why the production and the storage of hydrogen have recently been the subject of particular attention [6], because the exploitation of this gas as a clean fuel has many advantages [7]. Its impact on the environment is greatly reduced and comes from a clean and sustainable renewable energy source. Hydrogen will gradually replace non-renewable energies for clean energy purposes [8], as in fuel cells technologies for vehicles matrices with the expansion of $\mathrm{H}_{2}$ filling infrastructures in Europe [9]. However, the treatment of hydrogen as a fuel must have the same degree of risk as other conventional liquid and gaseous fuels and, since this gas operates at high pressure, its existence in a confined space presents a risk of explosion [10]. Therefore, the storage of hydrogen for commercial purposes with high gravimetric density is a major task [11,12]. Safe storage of large capacities is an essential step in the exploitation of hydrogen as renewable energy [13].

High strength steel coatings have been used on high pressure gas cylinders containing hydrogen or natural gas. Nevertheless, hydrogen penetration is possible in this coating layer, making the material brittle to withstand the damage caused by high pressures [14]. To be able to store energy on board, the success of fuel cells requires a compact, lightweight and affordable hydrogen storage system to replace pressurized hydrogen tanks under pressure [15]. Therefore, the challenge of its storage extremely confined its applications. Current researchers are mostly focused on the development of porous nanomaterials having large specific surface areas for improving the gravimetric densities, which undoubtedly restrain the volumetric densities of hydrogen storage [16]. The discovery of new hydrogen storage materials has advanced hydrogen storage technology in recent decades [17]. In this respect, various developed composite and nanostructured materials are currently considered promising candidates for the storage of hydrogen to supply fuel cells [15, 18-20].

In a previous work dealing with on the simultaneous generation and conditioning of hydrogen storage, under minimum pressure by continuous solar adsorption in activate carbon $\mathrm{AX}-21$ to supply a fuel cell [21], the adsorption rate of $\mathrm{H}_{2}$ was modeled to be suitable for production rate. 
The system used adsorbent beds as a storage unit that could play two roles, one as a fuel storage tank and the other as a fuel supply unit, as shown in Fig.1. The previous work did not deal with the second role of the storage unit, which will be studied in this work.

While the high-density reversible hydrogen storage as a vehicular fuel is a biggest challenge [22] and a reliable, efficient, and affordable medium that can store hydrogen reversibly at ambient temperature and pressure for on-board applications is also current challenge for researchers worldwide [23], one of the main technical barriers associated with adsorbent-based hydrogen storage systems are their ability to effectively discharge hydrogen, depending on the real-time demand of the fuel cell [24]. Hydrogen can be evacuated if necessary by increasing the temperature or decreasing the external pressure [25]. However, the hydrogen release rate is not easy to control because it also varies with the temperature and composition of the materials [26]. Graetz and Vajo [26] have developed a kinetic equation of rates from a series of isothermal measurements to describe the relationship between temperature, hydrogen release rate and composition for aluminum hydride and metastable hydrides, during operation of a fuel cell at a controlled rate of about $1 \% \mathrm{wt} \% / \mathrm{hr}$. Although different kinetic models of hydrogen desorption for some adsorbent materials have been reported in the literature [27-32], these models did not consider the control of hydrogen flow rate as a function of real-time demand of the fuel cell.

The objective of this work is therefore to develop a single model based on general equation to control the rate of hydrogen desorption when supplying the fuel cell. In such system, (i) the release of hydrogen from activated carbon AX-21, applied as an adsorbent material, is induced by the rise in temperature, and (ii) the hydrogen flow relies on the pressure difference between the adsorbent storage bed and the hydrogen inlet into the fuel cell. The inlet pressure is considered to be set at atmospheric pressure, and the pressure in the adsorbent bed is modeled using the modified DubininAstakhov equation [33], which proved to be a good analytical tool for describing hydrogen adsorption in a wide range of pressures and temperatures for several adsorbents [34] and in supercritical conditions [35].

The study presents a general mathematical model and a calculation algorithm for estimating the desorbed hydrogen flow rate (DHR) as a function of supply time and temperature. It proposes a 
condition to stabilize the DHR by controlling the monitoring of the flow section of the hydrogen supply of the fuel cell, thus controlling the generated power and time.

\section{System scheme}

To release hydrogen gas to the fuel cell, a desorption process is required by heating the absorbent bed in ambient air at room temperature to increase the pressure of the stored hydrogen [21]. In our system, the adsorption is automatically synchronized with an intermittent solar energy source. Thus, during the day, the solar irradiation is used to heat the beds and to desorb the hydrogen gas, while at night the water of hot fluid tank is used in place of the solar radiation.

The evaluation of heat exchange in the system can be based mainly on the work of Cherrad et al. $[36,37]$. The opening of the valve, which connects the outlet of the adsorbent bed and the fuel cell inlet (Fig. 1), induces the flow of gas into the fuel cell by pressure difference. However, this difference becomes stable when the two pressures are equal in the adsorbent bed and at the fuel cell inlet, and does not guarantee the release of all of the excess hydrogen stored hydrogen. The solution to release a maximum of fuel is therefore the increase of the temperature of the adsorbent bed.

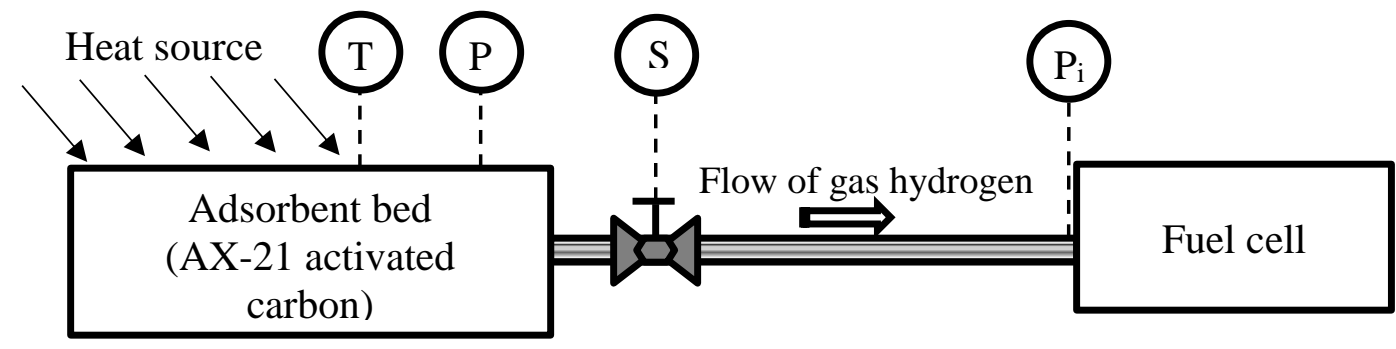

Fig. 1. Hydrogen desorption scheme for supplying the fuel cell

\section{Mathematical modeling of DHR}

To evaluate and optimize the performance of hydrogen storage systems, it is necessary to take into account the thermodynamic characteristics, in particular temperature and pressure [38]. 
- Hydrogen adsorption

From the modified Dubinin-Astakhov equation, it can be estimated the excess amount of hydrogen $\left(\mathrm{m}_{\mathrm{h}}\right)$ in $\mathrm{kg}$ per $\mathrm{kg}$ of adsorbent material as a function of pressure and temperature, as follows.

$m_{h}=M_{h} \cdot\left(n_{\max } \exp \left[-\left[\frac{R \cdot T}{\alpha+\beta . T}\right]^{2} \ln ^{2}\left(\frac{P_{0}}{P}\right)\right]-\rho_{g} \cdot V_{a}\right)$

The adsorption storage phase occurs at a low temperature (liquid nitrogen temperature of about $195.79^{\circ} \mathrm{C}$ ) and at a pressure close to that of the atmosphere. Heating the adsorbent bed to room temperature $\mathrm{T}_{\mathrm{amb}}$ increases the pressure. The higher the temperature, the more the pressure increases. The density of the bulk gas $\rho_{\mathrm{g}}$ is estimated using the state equation of an ideal gas at atmospheric pressure:

$\rho_{g}=\frac{P_{a t m}}{R \cdot T}$

In the case of the activated carbon AX-21, as adsorbent material, the data of the modified DubininAstakhov model parameters are given in Table 1.

Table 1: Modified Dubinin-Astakhov model parameters in the case of the AX-21 activated carbon [33].

\begin{tabular}{|l|l|}
\hline Parameter & Value \\
\hline $\mathrm{n}_{\max }$ & $71.6 \mathrm{~mol} / \mathrm{kg}$ \\
\hline $\mathrm{P}_{0}$ & $1470 \mathrm{Mpa}$ \\
\hline$\alpha$ & $3080 \mathrm{~J} / \mathrm{mol}$ \\
\hline$\beta$ & $18.9 \mathrm{~J} /(\mathrm{mol} . \mathrm{K})$ \\
\hline $\mathrm{V}_{\mathrm{a}}$ & $0.00143 \mathrm{~m}^{3} / \mathrm{kg}$ \\
\hline $\mathrm{M}_{\mathrm{h}}$ & $2.0159 \times 10^{-3} \mathrm{~kg} / \mathrm{mol}$ \\
\hline $\mathrm{R}$ & $8.314 \mathrm{~J} /(\mathrm{mol} . \mathrm{K})$ \\
\hline
\end{tabular}


It results that for a given stored excess of hydrogen and a given temperature of the adsorbent bed, the pressure in the adsorbent bed can be deduced from equation (1) as follows:

$$
P\left(T, m_{h}\right)=\frac{P_{0}}{\exp \left[\frac{\sqrt{\ln \left[\frac{n_{\max }}{\frac{m_{h}}{M_{h}}+\rho_{g} \cdot V_{a}}\right]}}{\left[\frac{R \cdot T}{\alpha+\beta . T}\right]}\right]}
$$

Equation (3) above means that the pressure in the adsorbent can be controlled for the same constant values in table (1) and the different parameters which can be modified.

- Hydrogen desorption

The desorption of hydrogen from activated carbon AX-21 occurs at the same time as the fuel cell supply. It can be calculated from the dynamic pressure deduced from the difference of the static pressure between the adsorbent bed and the admission of the fuel cell (pressure $\mathrm{P}_{\mathrm{i}}$ ). Thus, the desorption rate of hydrogen desorption is expressed by:

$V_{\text {des }}=\sqrt{\frac{2\left(P-P_{i}\right)}{M_{h} \cdot \rho_{g}}}$

The mass flow of hydrogen depends on the flow section $\mathrm{S}$ of the valve as shown in Fig. 1 and is described as follows:

$q_{d e s}=M_{h} \cdot \rho_{g} . S \cdot V_{d e s}$

During desorption, the excess amount of stored hydrogen in adsorbent material decreases with time and can be estimated by the following equation:

$m_{h}^{t+\Delta t}=m_{h}^{t}-\frac{q_{d e s} \cdot \Delta t}{m_{d}}$

\section{Numerical modeling of DHR}

The process stops if one of the below conditions is verified:

$\frac{\left|P-P_{i}\right|}{P_{i}} \leq \varepsilon$ 
Or

$\frac{\left|m_{h}{ }^{t}-m_{h}{ }^{t=0}\right|}{m_{h}{ }^{t}} \leq \varepsilon$

Verification of the condition of equation (7) does not mean that all the excess amount of stored hydrogen has been released, because the pressure P (equation (3)) depends on the temperature of the adsorbent material and the amount of hydrogen (not yet described). To realize the maximum of the excess hydrogen, the temperature must be increased to increase the pressure until the condition of the equation (8) is verified. At this point, no hydrogen can be desorbed from the adsorbent material.

An iterative process with time variation is necessary for equation (8) to estimate the change in mass flow of hydrogen during the hydrogen supply of the fuel cell. The computational algorithm for the DHR model is shown in Fig. 2. 


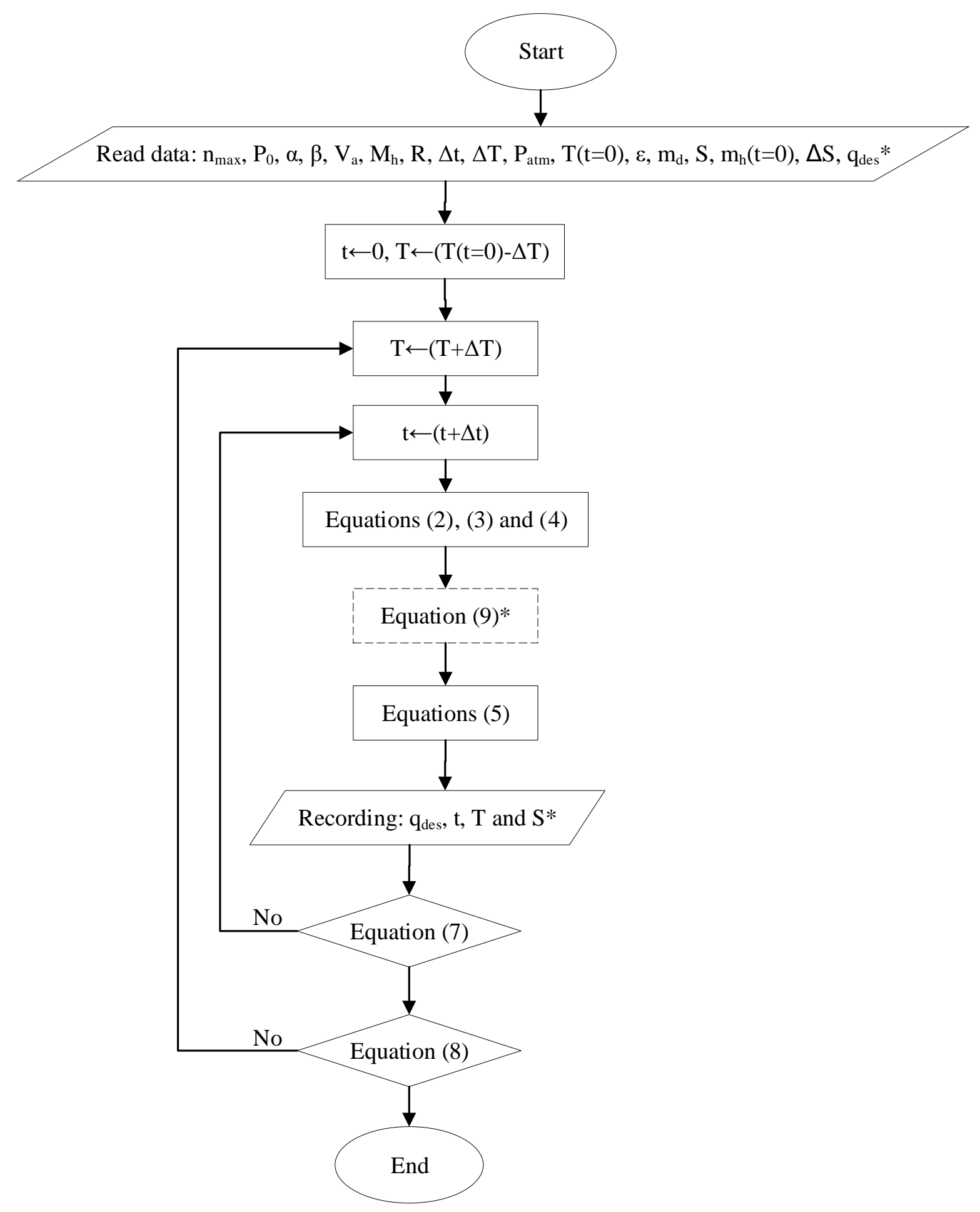

* Only for a constant mass flow rate $\mathrm{q}_{\text {des }}$

Fig.2. Computational algorithm of DHR model to estimate the variation of the mass flow of desorbed hydrogen during the supply of the fuel cell. 


\section{Results}

\subsection{DHR variation}

The variation of the desorbed hydrogen flow rate as a function of time was first estimated at the storage temperature $\mathrm{T}=-195.79{ }^{\circ} \mathrm{C}$ and at atmospheric pressure (considered for adsorption storage phase when the liquid nitrogen is used as cooling fluid), for a flow section set a at $1 \mathrm{~mm}^{2}$ and an initial excess of hydrogen stored $m_{h}=50 \mathrm{~g}$ for $1 \mathrm{~kg}$ of adsorbent material having a mass of 100 $\mathrm{kg}$. When the adsorbent bed was heated to ambient air, the pressure increases automatically, while the pressure at the fuel inlet remains atmospheric $\left(\mathrm{P}_{\mathrm{i}}=\mathrm{P}_{\mathrm{atm}}\right)$.

Fig.3(A) clearly shows the decrease in the mass flow rate of hydrogen other the time, resulting from the decrease in the difference between the pressures of the adsorbent bed and the fuel cell inlet, as shown in Fig.3(B).

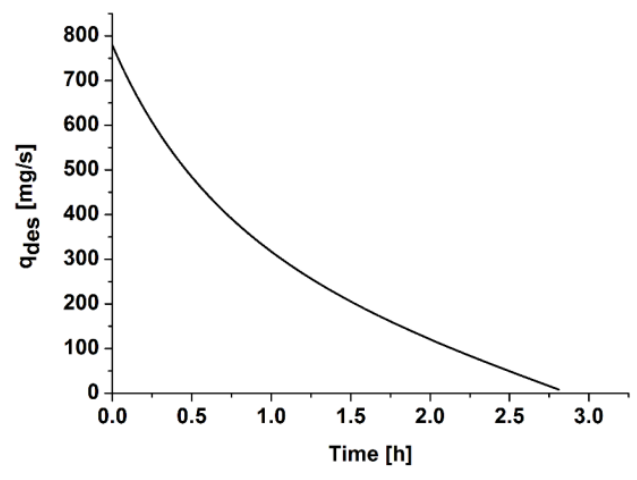

(A)

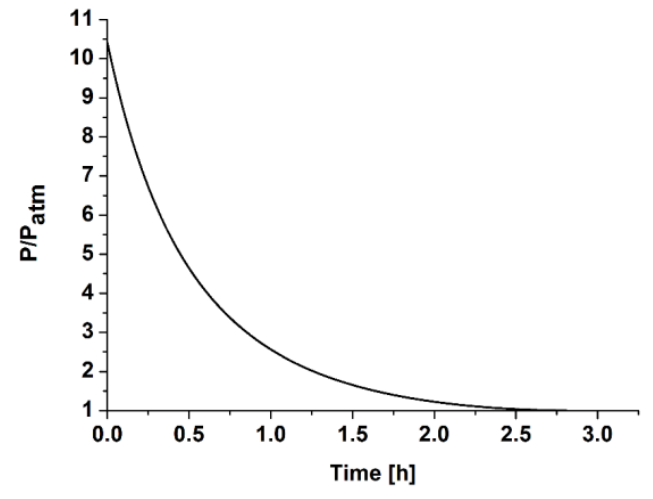

(B)

Fig.3. (A) variation of desorbed hydrogen rate as a function of time, (B) variation of the pressure in the adsorbent bed as a function of time, with $\mathrm{S}=1 \mathrm{~mm}^{2}$, initial $\mathrm{m}_{\mathrm{h}}=50 \mathrm{~g} / \mathrm{kg}$ and $\mathrm{T}=$ $-195.79^{\circ} \mathrm{C}$.

\subsection{Released excess amount}

Fig. 4 shows that the excess amount of stored hydrogen is completely released from temperature above $-50^{\circ} \mathrm{C}$. This observation results from the significant increase of the initial pressure in the adsorbent material with temperature. Higher pressures obtained from ambient temperatures are useful for transporting hydrogen over a long distance. A positive result, seen in Fig. 4, is the 
complete release of hydrogen at ambient temperature, which minimizes the heating energy supplied to the desorption phase.

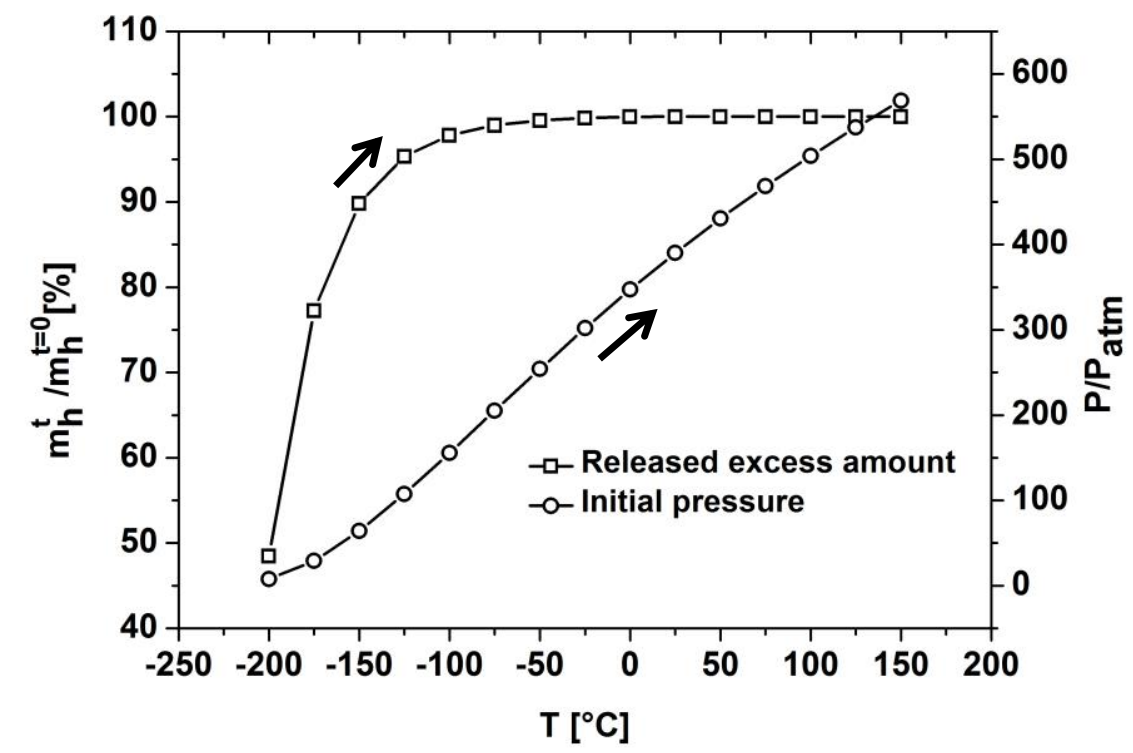

Fig.4. Excess amount of hydrogen released by the adsorbent material and the initial pressure relative to the desorption temperature $\left(S=1 \mathrm{~mm}^{2}\right.$ and initial $\left.\mathrm{m}_{\mathrm{h}}^{\mathrm{t}=0}=50 \mathrm{~g} / \mathrm{kg}\right)$.

\subsection{Desorption duration}

Fig.4 describes the relationship between excess hydrogen released and temperature. However, it may be rather useful to describe the desorption time of hydrogen as a function of temperature. As shown in Fig.5, increasing the temperature accelerates the release of hydrogen into the fuel cell. Which requires finding a way to stabilize it according to hydrogen demand of the fuel cell. The minimum desorption time occurs at high temperatures above $100^{\circ} \mathrm{C}$, after a total pressure drop. 


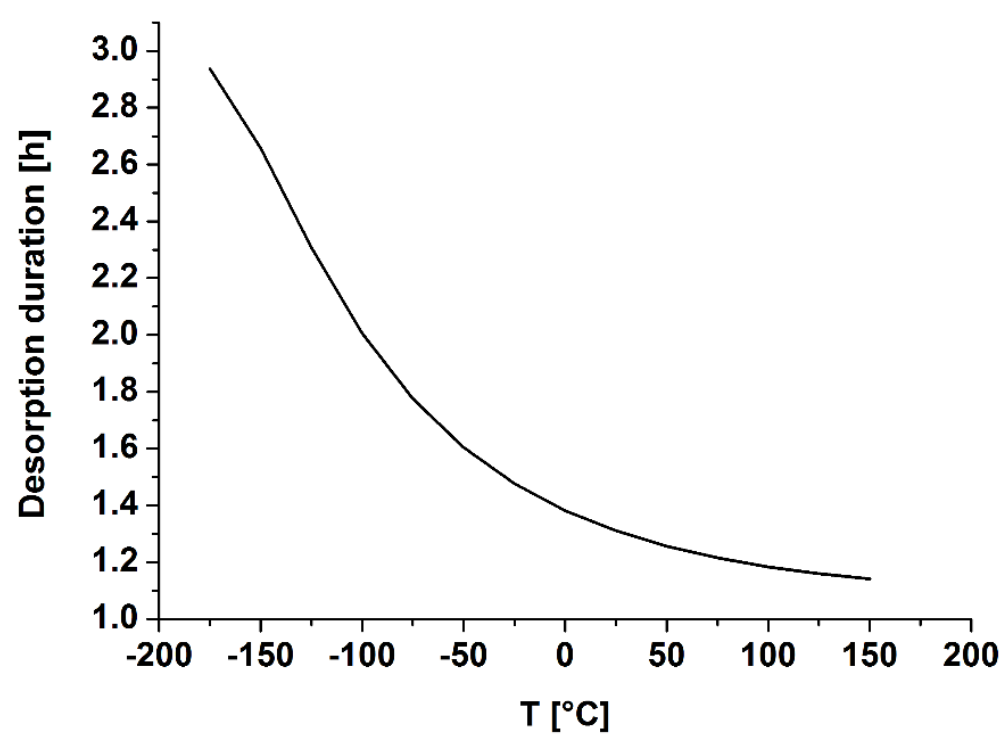

Fig.5. Duration of desorption as a function of temperature after a total pressure drop $\left(\mathrm{S}=1 \mathrm{~mm}^{2}\right.$ and initial $\left.\mathrm{m}_{\mathrm{h}}=50 \mathrm{~g} / \mathrm{kg}\right)$.

\subsection{Condition to stabilize the DHR}

The above results show that the desorbed hydrogen rate is not stable and may not be useful for the fuel cell, since a constant mass flow rate is required to produce a constant power. Precise mass flow control therefore requires controlling the flow section $\mathrm{S}$ of the valve (equation 5) to stabilize the desorption.

For a constant mass flow rate $\mathrm{q}_{\mathrm{des}}$ and a variable flow section $\mathrm{S}$, the condition to be verified is given as follows:

$S=\frac{q_{d e s}}{M_{h} \cdot \rho_{g} \cdot V_{d e s}}$

In this way, the flow section $S$ is controlled to ensure a constant supply of fuel. Fig. 6 shows the variation of the controlled flow section as a function of steady state supply and temperature. 


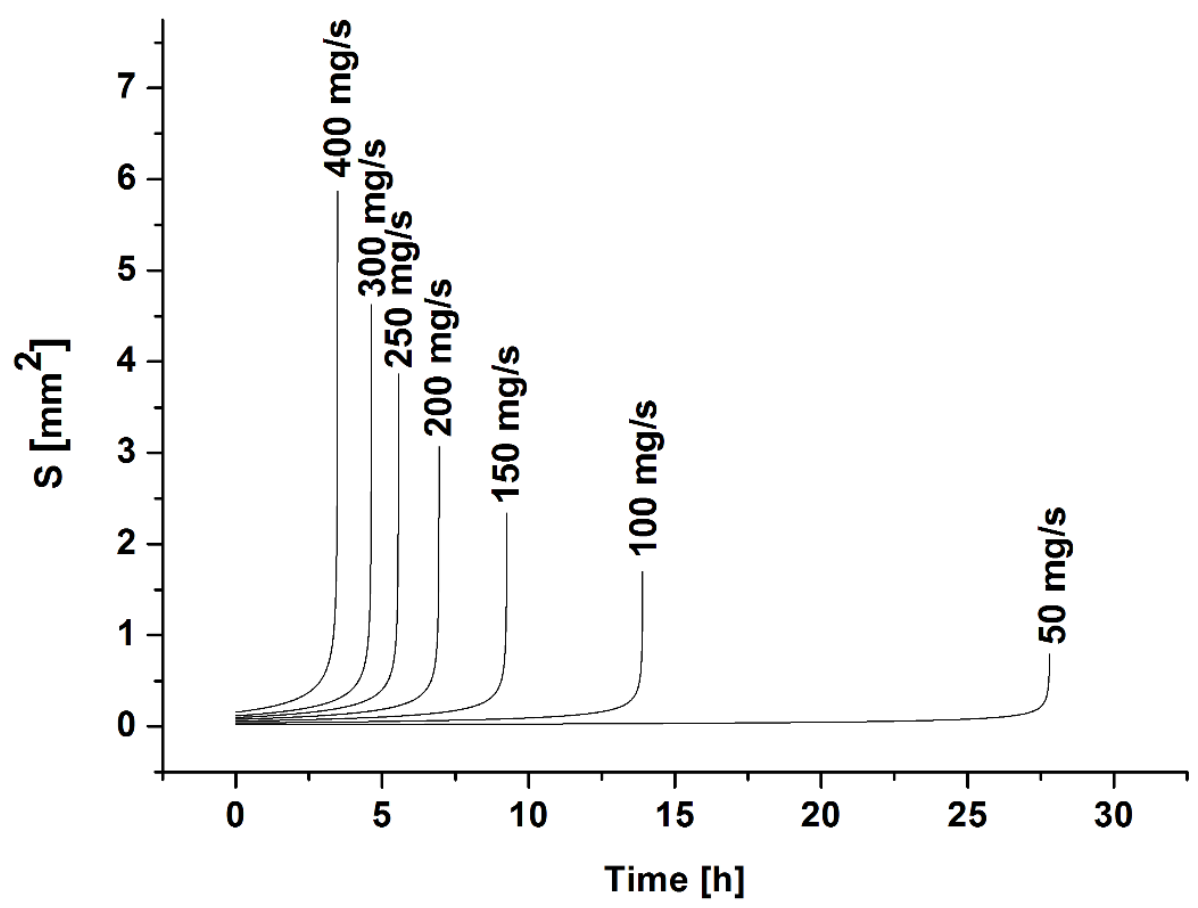

Fig.6. Variation of the controlled flow section versus stable desorbed hydrogen flow rates and supply time at ambient temperature $\left(\mathrm{T}=25^{\circ} \mathrm{C}\right)$.

By decreasing the stable mass flow rate, a slow enlargement of the flow section takes a long time to reach an accelerated magnification. The latter is necessary at the end of the desorption when the excess quantity of releasing hydrogen is exhausted. As a result, the maximum flow section can be controlled as a function of the stabilized mass flow rate for different ambient temperatures, as shown in Fig. 7. 


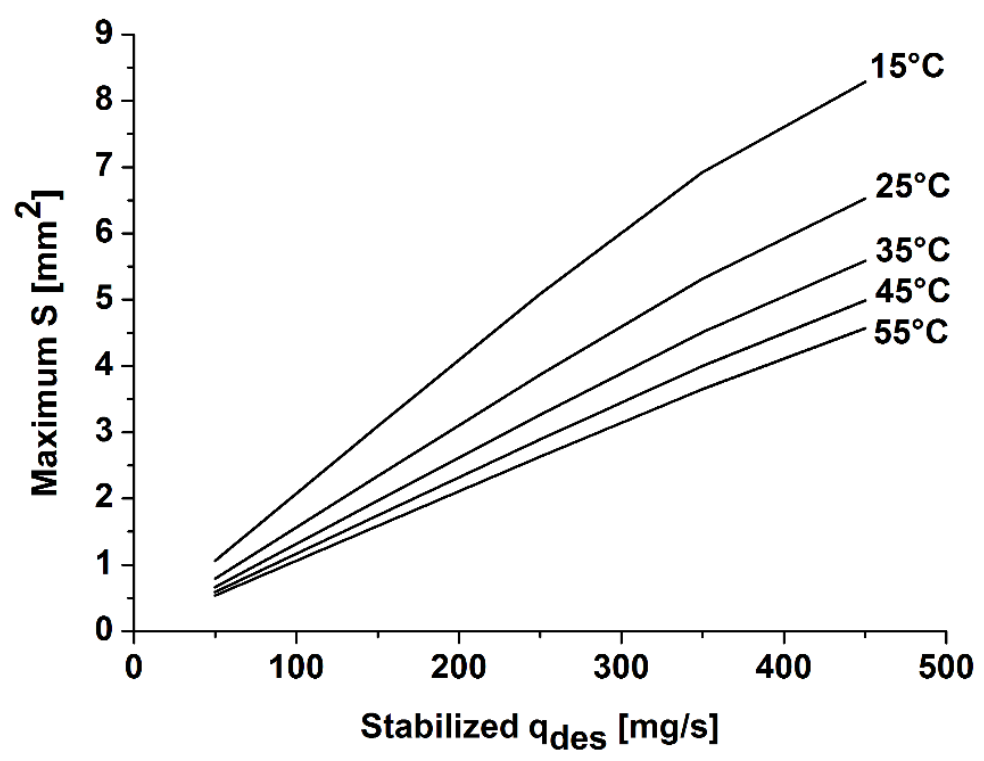

Fig.7. Variation of maximum flow section as a function of stabilized mass flow rate for different ambient temperatures.

We have found that the hydrogen mass flow rate depends on the fuel cell supply required to produce the required power. High flow sections in square millimeters have been selected to allow the desorption of hydrogen in its maximum capacity. However, during a long supplying period, it is possible to reduce the desorbed hydrogen rate by decreasing the flow section to the square micromillimeter $\left(\mu \mathrm{m}^{2}\right)$. Then, the key to regulating the desorbed hydrogen rate and its duration is the flow section for providing the appropriate hydrogen release rates to a fuel cell.

\subsection{Control of producing power of fuel cell}

The relationship between the amount of hydrogen consumed and the current supplied by the fuel cell is expressed as follows:

$q_{\text {des }}=\frac{I}{2 F} \cdot M_{h}$

where, I is the current delivered by the cell and F is the Faraday's constant.

For a given voltage $\mathrm{V}$, we can estimate the power $\mathrm{P}_{\mathrm{e}}$ produced by the fuel cell as a function of desorbed hydrogen rate using equation (10) as follows:

$P_{e}=\frac{2 V \cdot q_{\text {des }} \cdot F}{M_{h}}$ 
Fig. 8 shows the variation decrease of the generated power associated to the diminution of the mass flow rate as a function of the desorption time.

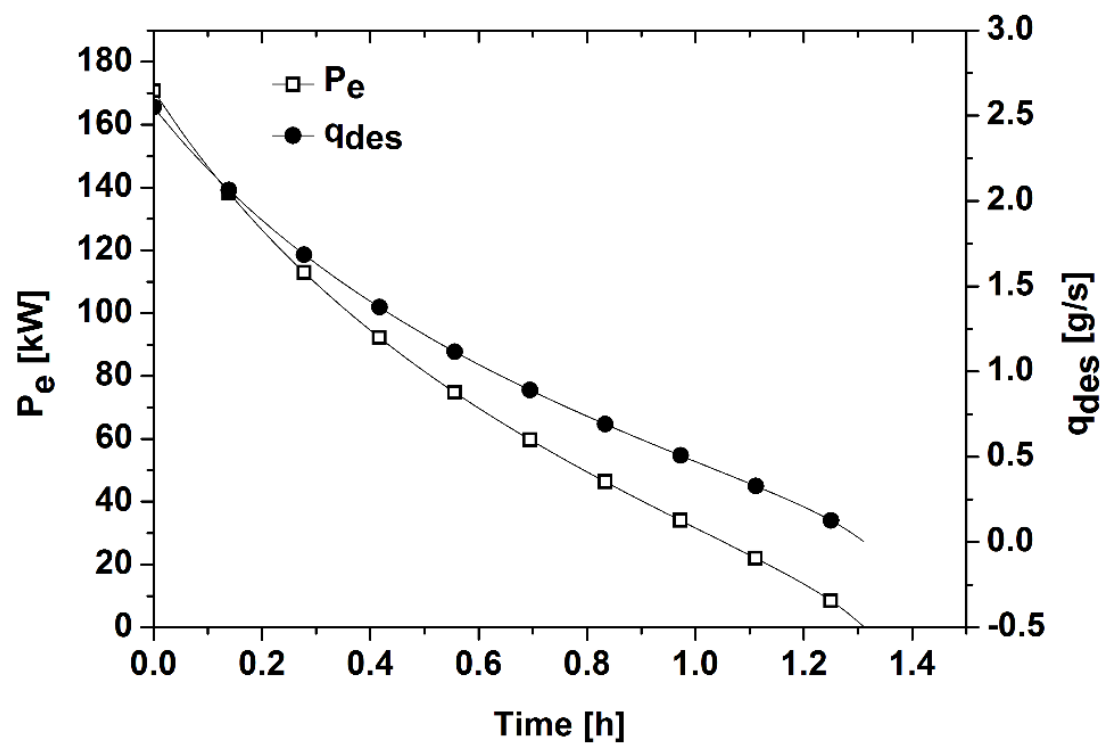

Fig.8. Variation of the produced power and the mass flow rate of hydrogen as a function of the desorption time $\left(\mathrm{T}=25^{\circ} \mathrm{C}, \mathrm{S}=1 \mathrm{~mm}^{2}\right.$ and $\left.\mathrm{V}=0.7 \mathrm{~V}\right)$.

By substituting equations (2), (4) and (5) in equation (11) it results the equation (12) where the flow section of the valve is expressed as a function of power to be produced:

$S=\frac{P_{e}}{2 V . F \cdot \sqrt{\frac{2 P_{a t m} \cdot\left(P-P_{i}\right)}{M_{h} \cdot R \cdot T}}}$

This means that the control of the valve of the control unit (Fig. 1) makes possible to adjust by automatic control the output power. The control unit can operate only by receiving a signal of four parameters as input data, namely: the temperature $\mathrm{T}$ and the pressure $\mathrm{P}$ in the adsorbent material, the pressure $\mathrm{P}_{\mathrm{i}}$ at the admission inlet of the fuel cell and the power $\mathrm{P}_{\mathrm{e}}$ selected by the user. A user control panel allows selecting the output power and display the power generation time before turning on the fuel cell. The control system program of the control unit can be based on the modeling of this study. 


\section{Conclusion}

A hydrogen desorption rate modeling during fuel cell fueling has been proposed. The system process is based on hydrogen storage by adsorption in AX-21 activated carbon material. The system control program is based on the DHR model of this study, in which an iterative process with time variation was presented to estimate the change in hydrogen mass flow supply.

It can be seen that the mass flow rate of hydrogen decreases with time as the pressure difference between the adsorbent bed and the fuel cell inlet decreases. The pressure drop at a lower desorption temperature cannot release all the excess amounts of hydrogen stored. The excess of hydrogen released by the adsorbent material after a total pressure drop is greater at high temperature than at low temperature. However, the excess hydrogen is completely released at ambient desorption temperatures, which is a better result in minimizing the heating energy supplied to the desorption phase.

In addition, the minimum desorption time, after a total pressure drop, corresponds to higher temperatures. The results show that the DHR is not stable, which is why a condition has been proposed to stabilize the desorption rate by controlling the feed section of the fuel cell. However, another study also seems necessary to estimate the thermal energy supplied to the hydrogen desorption process.

\section{References}

[1] A.M. Abdalla, S. Hossain, O.B. Nisfindy, A.T. Azad, M. Dawood, A.K. Azad, Hydrogen production, storage, transportation and key challenges with applications: A review, Energy $\begin{array}{lllll}\text { Conversion and } & \text { Management } & 65 & \text { (2018) }\end{array}$ https://doi.org/10.1016/j.enconman.2018.03.088.

[2] F. Dawood, M. Anda, G.M. Shafiullah, Hydrogen production for energy: An overview, International Journal of Hydrogen Energy 45 (2020) 3847-3869. doi: https://doi.org/10.1016/j.ijhydene.2019.12.059.

[3] T. Sinigaglia, F. Lewiski, M.E. Santos Martins, J.C. Mairesse Siluk, Production, storage, fuel stations of hydrogen and its utilization in automotive applications-a review, International Journal of Hydrogen Energy 42 (2017) 24597-24611. doi: https://doi.org/10.1016/j.ijhydene.2017.08.063.

[4] V. Sharma, H.L. Kagdada, J. Wang, P.K. Jha, Hydrogen adsorption on pristine and platinum decorated graphene quantum dot: A first principle study, International Journal of Hydrogen Energy (2019). doi: https://doi.org/10.1016/j.ijhydene.2019.09.021. 
[5] O. Czakkel, B. Nagy, G. Dobos, P. Fouquet, E. Bahn, K. László, Static and dynamic studies of hydrogen adsorption on nanoporous carbon gels, International Journal of Hydrogen Energy 44 (2019) 18169-18178. doi: https://doi.org/10.1016/j.ijhydene.2019.05.131.

[6] D. Czylkowski, B. Hrycak, R. Miotk, M. Jasiński, M. Dors, J. Mizeraczyk, Hydrogen-enriched gas production from kerosene using an atmospheric pressure microwave plasma system, Fuel 215 (2018) 686-694. doi: https://doi.org/10.1016/j.fuel.2017.11.137.

[7] S.H. Md Arshad, N. Ngadi, A.A. Aziz, N.S. Amin, M. Jusoh, S. Wong, Preparation of activated carbon from empty fruit bunch for hydrogen storage, Journal of Energy Storage 8 (2016) 257-261. doi: https://doi.org/10.1016/j.est.2016.10.001.

[8] R. Oriňáková, A. Oriňák, Recent applications of carbon nanotubes in hydrogen production and storage, Fuel 90 (2011) 3123-3140. doi: https://doi.org/10.1016/j.fuel.2011.06.051.

[9] Germany adds more hydrogen stations in Wolfsburg, Ingolstadt, Fuel Cells Bulletin 2018 (2018) 7. doi: https://doi.org/10.1016/S1464-2859(18)30116-0.

[10] L.C. Shirvill, T.A. Roberts, M. Royle, D.B. Willoughby, P. Sathiah, Effects of congestion and confining walls on turbulent deflagrations in a hydrogen storage facility-part 1: Experimental study, International Journal of Hydrogen Energy 43 (2018) 7618-7642. doi: https://doi.org/10.1016/j.ijhydene.2018.02.135.

[11] R.Y. Sathe, S. Kumar, T.J. Dhilip Kumar, First-principles study of hydrogen storage in metal functionalized [4,4]paracyclophane, International Journal of Hydrogen Energy 43 (2018) 56805689. doi: https://doi.org/10.1016/j.ijhydene.2018.01.159.

[12] H. Barthelemy, M. Weber, F. Barbier, Hydrogen storage: Recent improvements and industrial perspectives, International Journal of Hydrogen Energy 42 (2017) 7254-7262. doi: https://doi.org/10.1016/j.ijhydene.2016.03.178.

[13] K. Edalati, R. Uehiro, Y. Ikeda, H.-W. Li, H. Emami, Y. Filinchuk, M. Arita, X. Sauvage, I. Tanaka, E. Akiba, Z. Horita, Design and synthesis of a magnesium alloy for room temperature $\begin{array}{lllllll}\text { hydrogen } & \text { storage, } & \text { Acta } & \text { Materialia } & 149 & \text { (2018) 88-96. } & \text { doi: }\end{array}$ https://doi.org/10.1016/j.actamat.2018.02.033.

[14] S.J. Yoon, H.J. Lee, K.B. Yoon, Y.W. Ma, U.B. Baek, Hydrogen damage in 34CrMo4 pressure vessel steel with high tensile strength, Journal of Mechanical Science and Technology 32 (2018) 637-646. doi: 10.1007/s12206-018-0111-7.

[15] T. Sadhasivam, H.-T. Kim, S. Jung, S.-H. Roh, J.-H. Park, H.-Y. Jung, Dimensional effects of nanostructured $\mathrm{Mg} / \mathrm{MgH} 2$ for hydrogen storage applications: A review, Renewable and Sustainable Energy Reviews 72 (2017) 523-534. doi: https://doi.org/10.1016/j.rser.2017.01.107.

[16] G. Nabi, M.A. Kamran, T. Alharbi, M. Rafique, M.B. Tahir, S. Hussain, N.R. Khalid, T. Iqbal, M. Shakil, C. Cao, Gallium vacancies role in hydrogen storage of single-crystalline GaN hexagonal micro-sheets, International Journal of Hydrogen Energy 45 (2020) 4731-4742. doi: https://doi.org/10.1016/j.ijhydene.2019.12.042. 
[17] Y. Wang, Y. Wang, Recent advances in additive-enhanced magnesium hydride for hydrogen storage, Progress in Natural Science: Materials International 27 (2017) 41-49. doi: https://doi.org/10.1016/j.pnsc.2016.12.016.

[18] S. Garroni, A. Santoru, H. Cao, M. Dornheim, T. Klassen, C. Milanese, F. Gennari, C. Pistidda, Recent progress and new perspectives on metal amide and imide systems for solid-state hydrogen storage, Energies 11 (2018) 1027. doi.

[19] F. Li, S. Bashir, J.L. Liu, Nanostructured Materials for Next-Generation Energy Storage and Conversion: Fuel Cells, Springer, 2018.

[20] D.P. Broom, Hydrogen storage materials: the characterisation of their storage properties, Springer Science \& Business Media, 2011.

[21] N. Cherrad, Conditioning of hydrogen storage by continuous solar adsorption in activated carbon AX-21 with simultaneous production, International Journal of Hydrogen Energy (2018). doi: https://doi.org/10.1016/j.ijhydene.2018.05.023.

[22] R.Y. Sathe, H. Bae, H. Lee, T.J. Dhilip Kumar, Hydrogen storage capacity of low-lying isomer of C24 functionalized with Ti, International Journal of Hydrogen Energy 45 (2020) 9936-9945. doi: https://doi.org/10.1016/j.ijhydene.2020.02.016.

[23] S.u. Rather, Preparation, characterization and hydrogen storage studies of carbon nanotubes and their composites: A review, International Journal of Hydrogen Energy 45 (2020) 4653-4672. doi: https://doi.org/10.1016/j.ijhydene.2019.12.055.

[24] C. Corgnale, B. Hardy, R. Chahine, D. Cossement, Hydrogen desorption using honeycomb finned heat exchangers integrated in adsorbent storage systems, Applied Energy 213 (2018) 426434. doi: https://doi.org/10.1016/j.apenergy.2018.01.003.

[25] I.P. Jain, C. Lal, A. Jain, Hydrogen storage in Mg: A most promising material, International Journal of Hydrogen Energy 35 (2010) 5133-5144. doi: https://doi.org/10.1016/j.ijhydene.2009.08.088.

[26] J. Graetz, J.J. Vajo, Controlled hydrogen release from metastable hydrides, Journal of Alloys and Compounds 743 (2018) 691-696. doi: https://doi.org/10.1016/j.jallcom.2018.01.390.

[27] Y. Kitagawa, K. Tanabe, Development of a kinetic model of hydrogen absorption and desorption in magnesium and analysis of the rate-determining step, Chemical Physics Letters 699 (2018) 132-138. doi: https://doi.org/10.1016/j.cplett.2018.03.036.

[28] M. Ma, L. Wang, B. Tang, P. Lyu, W. Xiang, Y. Wang, X. Tan, Kinetics of hydrogen desorption from titanium hydride under isothermal conditions, International Journal of Hydrogen Energy 43 (2018) 1577-1586. doi: https://doi.org/10.1016/j.ijhydene.2017.11.103.

[29] T. Yang, Q. Li, N. Liu, C. Liang, F. Yin, Y. Zhang, Improved hydrogen absorption and desorption kinetics of magnesium-based alloy via addition of yttrium, Journal of Power Sources 378 (2018) 636-645. doi: https://doi.org/10.1016/j.jpowsour.2018.01.003. 
[30] T. Yang, P. Wang, Q. Li, C. Xia, F. Yin, C. Liang, Y. Zhang, Hydrogen absorption and desorption behavior of Ni catalyzed Mg-Y-C-Ni nanocomposites, Energy 165 (2018) 709-719. doi: https://doi.org/10.1016/j.energy.2018.09.132.

[31] I.E. Gabis, A.P. Voit, E.A. Evard, Y.V. Zaika, I.A. Chernov, V.A. Yartys, Kinetics of hydrogen desorption from the powders of metal hydrides, Journal of Alloys and Compounds 404406 (2005) 312-316. doi: https://doi.org/10.1016/j.jallcom.2005.02.090.

[32] K.A. Terrani, M. Balooch, D. Wongsawaeng, S. Jaiyen, D.R. Olander, The kinetics of hydrogen desorption from and adsorption on zirconium hydride, Journal of Nuclear Materials 397 (2010) 61-68. doi: https://doi.org/10.1016/j.jnucmat.2009.12.008.

[33] M.-A. Richard, P. Bénard, R. Chahine, Gas adsorption process in activated carbon over a wide temperature range above the critical point. Part 1: modified Dubinin-Astakhov model, Adsorption 15 (2009) 43-51. doi: 10.1007/s10450-009-9149-x.

[34] G. Sdanghi, S. Schaefer, G. Maranzana, A. Celzard, V. Fierro, Application of the modified Dubinin-Astakhov equation for a better understanding of high-pressure hydrogen adsorption on activated carbons, International Journal of Hydrogen Energy (2019). doi: https://doi.org/10.1016/j.ijhydene.2019.09.240.

[35] G. Sdanghi, V. Nicolas, K. Mozet, G. Maranzana, A. Celzard, V. Fierro, Modelling of a hydrogen thermally driven compressor based on cyclic adsorption-desorption on activated carbon, International Journal of Hydrogen Energy 44 (2019) 16811-16823. doi: https://doi.org/10.1016/j.ijhydene.2019.04.233.

[36] N. Cherrad, A. Benchabane, L. Sedira, A. Rouag, Effect of heating time of adsorber-collector on the performance of a solar adsorption refrigerator, International Journal of Mechanical and Materials Engineering 12 (2017) 7. doi: 10.1186/s40712-017-0077-3.

[37] N. Cherrad, A. Benchabane, L. Sedira, A. Rouag, Transient numerical model for predicting operating temperatures of solar adsorption refrigeration cycle, Applied Thermal Engineering 130 (2018) 1163-1174. doi: 10.1016/j.applthermaleng.2017.11.059.

[38] J. Xiao, P. Bénard, R. Chahine, Adsorption-desorption cycle thermodynamics for adsorptive hydrogen storage system, International Journal of Hydrogen Energy 41 (2016) 6139-6147. doi: https://doi.org/10.1016/j.ijhydene.2015.11.024. 